\title{
Additions to Occultibambusaceae (Pleosporales, Dothideomycetes): Unrevealing Palmicolous Fungi in China
}

\author{
Xian-Dong $\mathrm{Yu}^{1,+}+\mathbb{0}$, Sheng-Nan Zhang ${ }^{1,2,+} \oplus$, Ratchadawan Cheewangkoon ${ }^{2, *}$ and Jian-Kui Liu ${ }^{1,2, *}$ \\ 1 School of Life Science and Technology, Center for Informational Biology, University of Electronic Science and \\ Technology of China, Chengdu 611731, China; yuxiandong@std.uestc.edu.cn (X.-D.Y.); \\ zshengnanbio@gmail.com (S.-N.Z.) \\ 2 Department of Entomology and Plant Pathology, Faculty of Agriculture, Chiang Mai University, \\ Chiang Mai 50200, Thailand \\ * Correspondence: ratchadawan.c@cmu.ac.th (R.C.); liujiankui@uestc.edu.cn (J.-K.L.); \\ Tel.: +86-028-6183-1832 (J.-K.L.) \\ + These authors have contributed equally to this work and share first authorship.
}

check for updates

Citation: Yu, X.-D.; Zhang, S.-N.; Cheewangkoon, R.; Liu, J.-K. Additions to Occultibambusaceae (Pleosporales, Dothideomycetes) Unrevealing Palmicolous Fungi in China. Diversity 2021, 13, 516 https://doi.org/10.3390/d13110516

Academic Editor: Ipek Kurtboke

Received: 8 September 2021

Accepted: 20 October 2021

Published: 22 October 202

Publisher's Note: MDPI stays neutral with regard to jurisdictional claims in published maps and institutional affiliations.

Copyright: (c) 2021 by the authors. Licensee MDPI, Basel, Switzerland. This article is an open access article distributed under the terms and conditions of the Creative Commons Attribution (CC BY) license (https:// creativecommons.org/licenses/by/ $4.0 /)$.

\begin{abstract}
During a survey of microfungi associated with palms from karst formations, three novel ascomycetes were found from decaying petioles of Trachycarpus fortunei (Arecaceae) in Guizhou, China. Multi-gene phylogenetic analyses based on a combined SSU, ITS, LSU, RPB2 and TEF1 $\alpha$ sequence data showed that these collections were affiliated to Brunneofusispora and Neooccultibambusa in the family Occultibambusaceae. A new species Brunneofusispora inclinatiostiola is introduced. It is phylogenetically close to $B$. clematidis but represents a distinct lineage. Morphologically, it differs from the latter in having immersed ascomata with eccentric, periphysate ostiole and smaller ascospores. Morpho-phylogenetic evidence also revealed two new Neooccultibambusa species, N. kaiyangensis and $N$. trachycarpi. Together with the generic type $N$. chiangraiensis, they formed a distinct lineage within the genus Neooccultibambusa. Three novel palmicolous fungi of Occultibambusaceae are described, illustrated and notes on their identification are provided. The ecological significance of the new taxa and the phylogenetic relationship of genera in Occultibambusaceae is discussed.
\end{abstract}

Keywords: three new taxa; multi-gene; phylogeny; sexual morph; taxonomy

\section{Introduction}

Occultibambusaceae was established by Dai et al. [1] and typified by Occultibambusa D.Q. Dai \& K.D. Hyde, which is represented by Bambusicola-like and Massarina-like sexual morphs and a coelomycetous asexual morph with annellidic conidiogenous cells and pale brown, oblong conidia. Five genera are accepted in the family, viz. Brunneofusispora S.K. Huang \& K.D. Hyde, Neooccultibambusa Doilom \& K.D. Hyde, Occultibambusa D.Q. Dai \& K.D. Hyde, Seriascoma Phookamsak, D.Q. Dai \& K.D. Hyde and Versicolorisporium Sat. Hatak., Kaz. Tanaka \& Y. Harada [1-4]. Versicolorisporium is the genus that only has an asexual morph in the family but is clustered with Occultibambusa in recent phylogenetic studies $[2,5,6]$. The difference between Seriascoma and the other four genera is that its sexual morphs have stromatic ascomata under a clypeus [1,7]. Brunneofusispora was considered to be different because of phylogenetic distinction and the ascomata of the type species have long necks [4]. Neooccultibambusa resembles Occultibambusa, however they are phylogenetically distinct, and the former has hyphomycetous asexual morphs or produces chlamydospores in culture [3,8-10].

Most Occultibambusaceae species are saprobes and have been found on Ammophila arenaria (Poaceae), bamboo (Poaceae), Clematis subumbellata (Ranunculaceae), Magnolia denudate (Magnoliaceae), Pandanus sp. (Pandanaceae), Tectona grandis (Lamiaceae), or dead twigs of woody plants in freshwater and terrestrial habitats [1-14]. In this study, saprobic fungi on Trachycarpus fortunei (Arecaceae) from karst formations were collected 
in Guizhou province, China. Morphological examination and multi-gene phylogeny based on SSU, ITS, LSU, RPB2 and TEF1 $\alpha$ sequence data were carried out to identify these fungi, of which three new Occultibambusaceae species belong to Brunneofusispora and Neooccultibambusa were introduced, respectively.

\section{Materials and Methods}

\subsection{Isolation and Morphological Examination}

Decayed petioles of Trachycarpus fortunei (Arecaceae) were collected from Guiyang city, Guizhou province in China. The samples were brought back to the laboratory in plastic ziplock bags and stored at room temperature. Fungal fruiting bodies were observed using Motic SMZ 168-B stereo microscope and made into slides within water mounts by using a syringe needle. Morphological characters were observed using a Nikon ECLIPSE E200 stereo microscope and photographed by a Nikon ECLIPSE Ni-U compound microscope fitted with a Nikon DS-Ri2 digital camera. All the details of the morphological approaches used in this paper were based on Senanayake et al. [15]. Photographs were processed with Adobe Photoshop CS6 software (Adobe Systems Inc., San Jose, CA, USA). Isolations were obtained from single spore as described in Chomnunti et al. [16]. Herbarium specimens (dry petioles with fungal material) were deposited in the herbarium of Cryptogams, Kunming Institute of Botany Academia Sinica (HKAS), Kunming, China and the herbarium of Guizhou Academy of Agricultural Sciences (GZAAS), Guizhou, China. The isolates obtained in this study were deposited in China General Microbiological Culture Collection Center (CGMCC) and Guizhou Culture Collection (GZCC). The new taxa were registered in MycoBank [17].

\subsection{DNA Extraction, PCR Amplification and Sequencing}

A Trelief TM Plant Genomic DNA Kit (Beijing TsingKe Biotech Co., Ltd., Beijing, China) was used to extract total genomic DNA from fresh mycelia. DNA amplification was performed by a polymerase chain reaction (PCR). SSU, ITS, LSU, RPB2 and TEF1 $\alpha$ sequences were amplified using primer pairs NS1/NS4, ITS5/ITS4, LR0R/LR5, fRPB25F/fRPB2-7cR and 983F/2218R, respectively [18-21]. The amplification reactions were performed in $25 \mu \mathrm{L}$ PCR mixtures containing $22 \mu \mathrm{L}$ PCR MasterMix (Green) (TsingKe Co., Beijing, China), $1 \mu \mathrm{L}$ DNA template and $1 \mu \mathrm{L}$ of each primer $(10 \mu \mathrm{M} / \mathrm{L})$. The PCR thermal cycle program for SSU, ITS, LSU, RPB2 and TEF1 $\alpha$ amplification were as follows: initial denaturing step of $98{ }^{\circ} \mathrm{C}$ for $2 \mathrm{~min}$, followed by 35 cycles of denaturation at $98^{\circ} \mathrm{C}$ for $10 \mathrm{~s}$, annealing at $47^{\circ} \mathrm{C}(\mathrm{SSU}), 56{ }^{\circ} \mathrm{C}$ (ITS, LSU, RPB2), $61.7{ }^{\circ} \mathrm{C}(\mathrm{TEF} 1 \alpha)$ for $10 \mathrm{~s}$, elongation at $72{ }^{\circ} \mathrm{C}$ for $10 \mathrm{~s}$, and final extension at $72{ }^{\circ} \mathrm{C}$ for $5 \mathrm{~min}$. PCR products were checked on $1 \%$ agarose electrophoresis gels stained with Gel Red. The sequencing reactions were carried out with primers mentioned above by Beijing Tsingke Biotechnology Co., Ltd., Chengdu, China.

\subsection{Phylogenetic Analyses}

The quality of the new sequences was initially checked with Finch TV Version 1.4.0 (https:/ / digitalworldbiology.com/FinchTV (accessed on 1 December 2020)). The BLAST was performed to find the similar sequences that match our data. A concatenated dataset of the SSU, ITS, LSU, RPB2 and TEF1 $\alpha$ sequences was used for phylogenetic analyses with the inclusion of reference taxa from GenBank (Table 1). Sequences were aligned using MAFFT v.7 (http:/ / mafft.cbrc.jp/alignment/server / (accessed on 11 June 2021)) [22] and then checked visually and manually optimized using BioEdit v.7.0.9 [23]. Each dataset was concatenated with Mesquite v. 3.11 (http:/ / www.mesquiteproject.org/ (accessed on 11 June 2021)) for multi-gene analyses. Maximum likelihood (ML), maximum parsimony (MP) and bayesian inference (BI) were carried out as detailed in Dissanayake et al. [24]. The programs used include RAxMLGUI v. 1.0 [25], PAUP v.4.0b10 [26], MrModeltest 2.3 [27] and MrBayes v. 3.1.2 [28,29]. Phylogenetic tree was visualized 
by FigTree v.1.4.0 (http:/ / tree.bio.ed.ac.uk/software/figtree/ (accessed on 11 June 2021)), and the alignment was submitted in TreeBASE (Study ID S28856 (accessed on 7 October 2021)).

Table 1. Taxa used in the phylogenetic analyses and their corresponding GenBank accession numbers. The ex-type strains are indicated in bold and newly generated sequences are indicated in red.

\begin{tabular}{|c|c|c|c|c|c|c|}
\hline \multirow{2}{*}{ Species } & \multirow{2}{*}{$\begin{array}{c}\text { Voucher/Strain/ } \\
\text { Isolate }\end{array}$} & \multicolumn{5}{|c|}{ GenBank Accession Number } \\
\hline & & SSU & ITS & LSU & RPB2 & TEF1 $\alpha$ \\
\hline Brunneofusispora clematidis & MFLUCC 17-2070 & MT226685 & MT310615 & MT214570 & MT394692 & MT394629 \\
\hline Brunneofusispora hyalina & MFLUCC 21-0008 & MW485613 & MW260330 & MW287234 & MW512609 & MW512606 \\
\hline $\begin{array}{l}\text { Brunneofusispora } \\
\text { inclinatiostiola }\end{array}$ & CGMCC 3.20403 & MZ964884 & MZ964866 & MZ964875 & OK061075 & OK061069 \\
\hline Brunneofusispora inclinatiostiola & GZCC 21-0185 & MZ964885 & MZ964867 & MZ964876 & OK061076 & OK061070 \\
\hline Brunneofusispora sinensis & KUMCC 17-0030 & MH393556 & MH393558 & MH393557 & - & MH395329 \\
\hline Brunneofusispora sinensis & MFLUCC 20-0016 & MT159636 & MT159630 & MT159624 & MT159613 & MT159607 \\
\hline Brunneofusispora sp. & X135 & - & MK304223 & - & - & - \\
\hline Massarina rubi & CBS 691.95 & GU456301 & - & FJ795453 & FJ795470 & - \\
\hline Massarina rubi & MUT 4323 & - & KF636766 & KF636772 & - & - \\
\hline Massarina rubi & MUT 4887 & KT587318 & KR014359 & KP671721 & - & - \\
\hline $\begin{array}{c}\text { Neooccultibambusa } \\
\text { chiangraiensis }\end{array}$ & MFLUCC 12-0559 & KU712458 & KU712442 & KU764699 & - & KU872761 \\
\hline Neooccultibambusa jonesii & MFLUCC 16-0643 & KY111438 & - & KY111437 & - & - \\
\hline Neooccultibambusa kaiyangensis & CGMCC 3.20404 & MZ964886 & MZ964868 & MZ964877 & OK061077 & OK061071 \\
\hline Neooccultibambusa kaiyangensis & GZCC 21-0184 & MZ964887 & MZ964869 & MZ964878 & OK061078 & OK061072 \\
\hline Neooccultibambusa pandanicola & KUMCC 17-0179 & MG298942 & MG298941 & MG298940 & MG298944 & MG298943 \\
\hline $\begin{array}{c}\text { Neooccultibambusa } \\
\text { thailandensis }\end{array}$ & MFLUCC 16-0274 & MH260348 & MH275074 & MH260308 & MH412758 & MH412780 \\
\hline Neooccultibambusa trachycarpi & CGMCC 3.20405 & MZ964888 & MZ964870 & MZ964879 & OK061079 & OK061073 \\
\hline Neooccultibambusa trachycarpi & GZCC 21-0181 & MZ964889 & MZ964871 & MZ964880 & OK061080 & OK061074 \\
\hline Occultibambusa aquatica & MFLUCC 11-0006 & KX698112 & KX698114 & KX698110 & - & - \\
\hline Occultibambusa bambusae & MFLUCC 13-0855 & KU872116 & KU940123 & KU863112 & KU940170 & KU940193 \\
\hline Occultibambusa chiangraiensis & MFLUCC 16-0380 & KX655551 & - & KX655546 & KX655566 & KX655561 \\
\hline Occultibambusa fusispora & MFLUCC 11-0127 & - & KU940125 & KU863114 & KU940172 & KU940195 \\
\hline Occultibambusa jonesii & GZCC 16-0117 & KY628324 & - & KY628322 & KY814758 & KY814756 \\
\hline Occultibambusa kunmingensis & HKAS 102151 & MT864342 & MT627716 & MN913733 & MT878453 & MT954407 \\
\hline Occultibambusa maolanensis & GZCC 16-0116 & KY628325 & - & KY628323 & KY814759 & KY814757 \\
\hline Occultibambusa pustula & MFLUCC 11-0502 & KU872118 & KU940126 & KU863115 & - & - \\
\hline Ohleria modesta & CBS 141480 & KX650513 & KX650563 & KX650563 & KX650583 & KX650534 \\
\hline Ohleria modesta & MGC & - & KX650562 & KX650562 & KX650582 & KX650533 \\
\hline Seriascoma didymosporum & MFLUCC 11-0179 & KU872119 & KU940127 & KU863116 & KU940173 & KU940196 \\
\hline Seriascoma yunnanense & MFLU 19-0690 & MN174694 & - & MN174695 & MN210324 & MN381858 \\
\hline Versicolorisporium triseptatum & JCM 14775 & AB524501 & AB365596 & AB330081 & - & _- \\
\hline
\end{tabular}




\section{Results}

\subsection{Phylogenetic Analyses}

The reference dataset included representatives of the five accepted genera in Occultibambusaceae, as well as three Massarina rubi, which were detected by blastn search of our strains. Five gene loci SSU, ITS, LSU, RPB2 and TEF1 $\alpha$ were used to determine the phylogenetic placement of the new collections. The concatenated matrix comprised of 31 taxa with a total of 4556 characters (SSU: 1053 bp; ITS: 663 bp; LSU: 881 bp; RPB2: 948 bp; TEF1 $\alpha$ : 1011 bp) including gaps. Maximum likelihood (ML), Maximum-parsimony (MP) and Bayesian analysis of the combined dataset resulted in phylogenetic reconstructions with largely similar topologies. The best scoring ML tree (Figure 1) was selected to represent the relationships among taxa, in which a final likelihood value of $-19,906.313448$ is presented. The matrix had 1442 distinct alignment patterns. Estimated base frequencies were as follows: $\mathrm{A}=0.245814, \mathrm{C}=0.251328, \mathrm{G}=0.269846, \mathrm{~T}=0.233012$; substitution rates $\mathrm{AC}=1.712622, \mathrm{AG}=3.759418, \mathrm{AT}=1.465059, \mathrm{CG}=1.312466, \mathrm{CT}=8.469117, \mathrm{GT}=1.000000$. GTR+I+G is the best-fit model selected by AIC in MrModeltest based on each gene (SSU, ITS, LSU, RPB2 and TEF1 $\alpha$ ), which is used for maximum likelihood and Bayesian analysis. The maximum parsimonious dataset consists of 4,556 characters, of which 3381 characters were constant and 307 variable characters parsimony uninformative. Maximum parsimony analysis of the remaining 868 parsimony-informative characters resulted in 1000 trees with $\mathrm{TL}=2859, \mathrm{CI}=0.567, \mathrm{RI}=0.674, \mathrm{RC}=0.382$, and $\mathrm{HI}=0.433$. Six simultaneous Markov chains were run for 595,000 generations and trees were sampled every 1000 generation and 595 trees were obtained. The first 119 trees representing the burn-in phase of the analyses were discarded, while the remaining 476 trees were used for calculating posterior probabilities in the majority rule consensus tree (critical value for the topological convergence diagnostic is 0.01).

The six isolates obtained in this study grouped with Brunneofusispora and Neooccultibambusa based on the multi-gene phylogeny analyses. Two of them were sister to Brunneofusispora clematidis with strong support and can be recognized as a new species $B$. inclinatiostiola. The other four strains were closely related to the generic type $N$. chiangraiensis and formed a well-supported clade (Figure 1), of which two new species N. kaiyangensis and N. trachycarpi were recognized. Neooccultibambusa kaiyangensis clustered together with $N$. chiangraiensis but can be morphologically and phylogenetically distinguished, while $N$. trachycarpi showed to be sister to $N$. chiangraiensis and $N$. kaiyangensis.

\subsection{Taxonomy}

Brunneofusispora inclinatiostiola S.N. Zhang \& Jian K. Liu, sp. nov., Figure 2. 


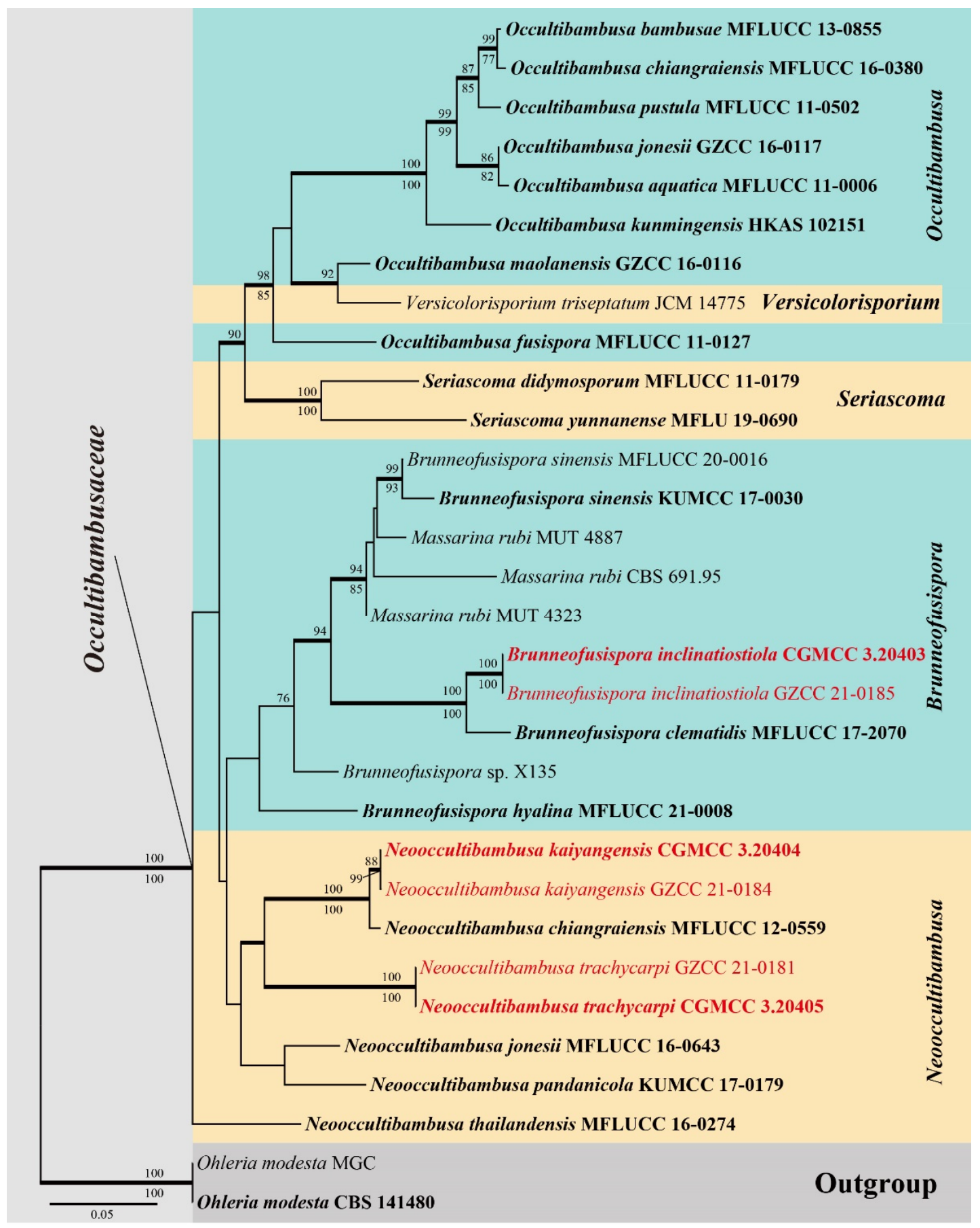

Figure 1. RAxML tree generated from combined SSU, ITS, LSU, RPB2 and TEF1 $\alpha$ sequence data. Bootstrap values for ML and MP equal to or greater than $75 \%$ are placed above and below the branches respectively. Branches with Bayesian posterior probabilities (PP) from MCMC analysis equal or greater than 0.95 are in bold. The tree is rooted with Ohleria modesta (CBS 141480) and O. modesta (MGC). The ex-type strains are indicated in bold and newly generated sequences are indicated in red. 

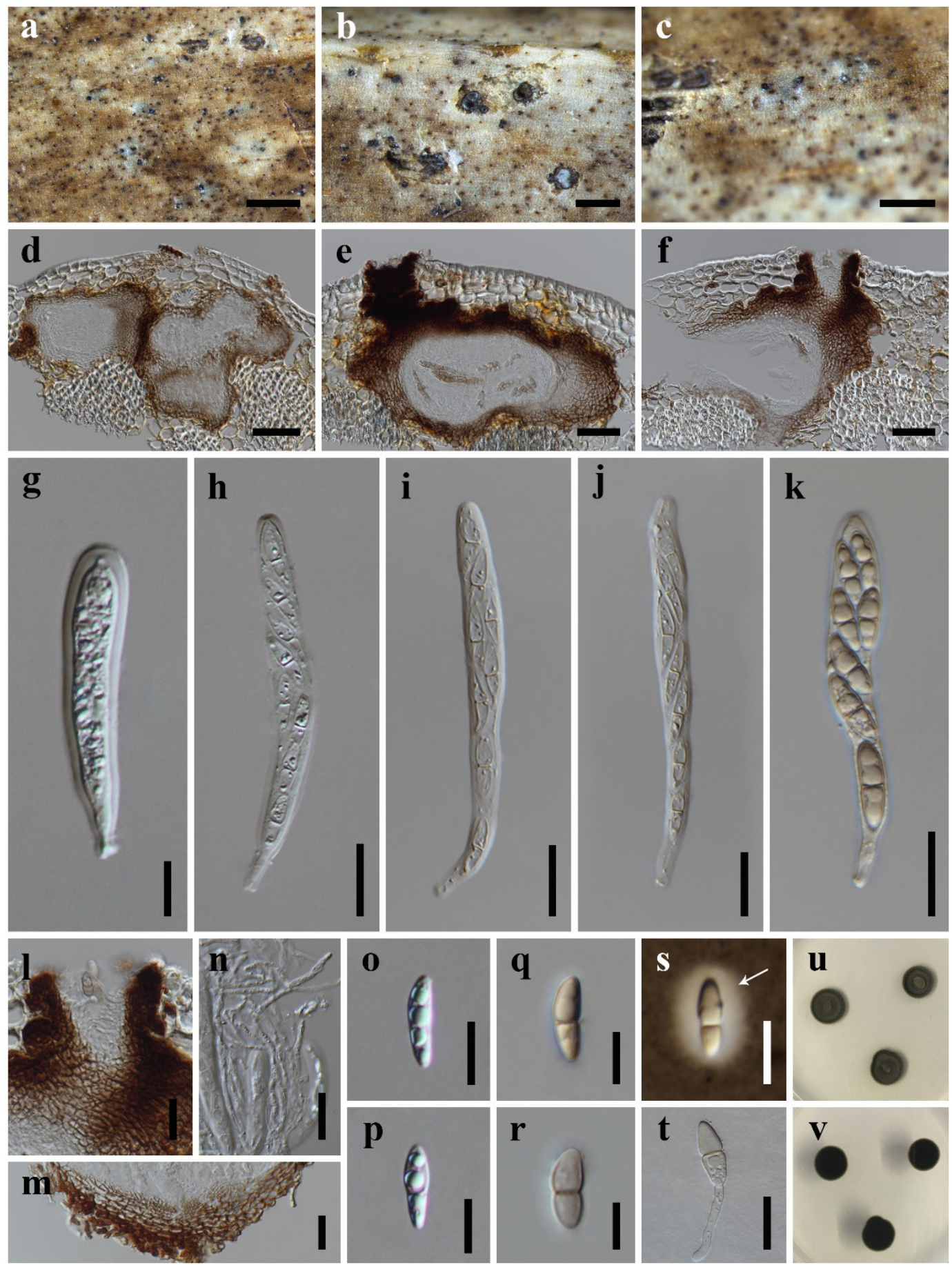

Figure 2. Brunneofusispora inclinatiostiola (HKAS 113022, holotype) (a-c) Ascomata on host substrate. (d-f) Vertical section of ascoma. (g-k) Asci. (1) Ostiole, showing periphyses. (m) Structure of peridium. (n) Pseudoparaphyses. (o-s) Ascospores (s) Arrow indicated mucilaginous sheath). (t) Germinated ascospore. (u,v) Colonies on PDA, above (u) and reverse $(\mathbf{v})$. Scale bars: $(\mathbf{a})=1000 \mu \mathrm{m},(\mathbf{b}, \mathbf{c})=,500 \mu \mathrm{m},(\mathbf{d}-\mathbf{f})=50 \mu \mathrm{m},(\mathbf{g}, \mathbf{o}-\mathbf{s})=10 \mu \mathrm{m},(\mathbf{h}-\mathbf{n}, \mathbf{t})=20 \mu \mathrm{m}$.

MycoBank: MB 841009;

Etymology: The epithet "inclinatiostiola" in reference to the incline ostiole.

Holotype: HKAS 113022

Saprobic on decaying petioles of Trachycarpus fortunei. Sexual morph: Ascomata are solitary, scattered to gregarious, immersed, slightly erumpent the host epidermis, visible as whitish-grey to pale brown area with a small black dot, in vertical section $90-230 \mu \mathrm{m}$ high, 150-340 $\mu \mathrm{m}$ diam., depressed globose or irregular subglobose, uniloculate, with 
an immersed ostiolar neck. Ostiole are usually ecentric, brown to black and periphysate. Peridium 15-55 $\mu \mathrm{m}$ wide, sometimes up to $70 \mu \mathrm{m}$ at the side, composed of several layers of hyaline to brown, thick-walled cells of textura angularis, darker and thicker outwardly. Hamathecium are 2.0-3.5 $\mu \mathrm{m}$ wide, cellular pseudoparaphyses, anastomosing above the asci, embedded in a gelatinous matrix. Asci 60-145 $\times 7.5-13.5 \mu \mathrm{m}(\bar{x}=100.6 \times 10.3 \mu \mathrm{m}, n=20)$, 8-spored, bitunicate, fissitunicate, cylindrical or cylindric-clavate, straight or slightly curved, short pedicellate, rounded at the apex, with an ocular chamber. Ascospores are $(13.5-) 14.0-19.0(-27.0) \times 4.0-6.5 \mu \mathrm{m}(\bar{x}=17.4 \times 4.7 \mu \mathrm{m}, n=50)$, uniseriate to partially biseriate, fusiform to ellipsoidal, hyaline, becoming pale brown at maturity, 1-septate, the upper cell slightly wider than the lower cell, guttulate when young, smooth-walled, surrounded by a mucilaginous sheath. Asexual morph: Undetermined.

Culture characteristics: Colonies on PDA reaching 12-15 mm diam. after 21 days at $25{ }^{\circ} \mathrm{C}$, circular, raised to umbonate, the margin entire, dark green, surface rough, dry, cottony, reverse dark green to black.

Material examined: CHINA, Guizhou Province, Guiyang City, Kaiyang County, Nanjiang Gorge Scenic Area, 26 57' $24^{\prime \prime}$ N, 106 59'19' E, $2900 \mathrm{ft}$ Elevation, on decaying petioles of Trachycarpus fortunei (Arecaceae), 19 March 2019, S.N. Zhang, SNC56 (HKAS 113022, holotype); ex-type living culture CGMCC 3.20403; ibid., $26^{\circ} 57^{\prime} 36^{\prime \prime} \mathrm{N}, 106^{\circ} 59^{\prime} 34^{\prime \prime} \mathrm{E}, 2860$ $\mathrm{ft}$ Elevation, on decaying petioles of Trachycarpus fortunei (Arecaceae), 19 March 2019, S.N. Zhang, SNC51 (GZAAS 21-0046, paratype); living culture GZCC 21-0185.

Notes: Brunneofusispora inclinatiostiola resembles B. clematidis in having fusiform to ellipsoidal ascospores surrounded by mucilaginous sheaths [13]. However, $B$. inclinatiostiola has smaller ascospores than that of B. clematidis $((13.5-) 14.0-19.0(-27.0) \times 4.0-6.5 \mu \mathrm{m}$ vs. $17-35 \times 5-10 \mu \mathrm{m})$. The phylogenetic results (Figure 1 ) indicated that $B$. inclinatiostiola is a phylogenetically distinct species. In addition, the comparison of nucleotide differences between $B$. inclinatiostiola and B. clematidis showed that there are $5.0 \%(23 / 460)$ differences in ITS, $2.4 \%(21 / 868)$ in RPB2 and 4.3\% (25/577) in TEF1 $\alpha$ gene regions, which also supports the introduction of $B$. inclinatiostiola as a new species.

Neooccultibambusa kaiyangensis X.D. Yu, S.N. Zhang \& Jian K. Liu, sp. nov., Figure 3. MycoBank: MB 841010;

Etymology: The epithet "kaiyangensis" in reference to Kaiyang County, where the fungus was collected.

Holotype: HKAS 113021.

Saprobic on rachides or petioles of palms. Sexual morph: Ascomata are scattered to gregarious, immersed, visible as brown or dark area with erumpent black dots on host surface, in vertical section 200-360 $\mu \mathrm{m}$ high, 110-270 $\mu \mathrm{m}$ diam., coriaceous, uniloculate, ampulliform, or globose with an ostiolar neck beneath the host surface. Ostiole are central, periphysate. Peridium are 16.5-38.0 $\mu \mathrm{m}$ wide, comprising several layers of brown, thin-walled cells of textura intricate, and hyaline, compressed cells of textura angularis. Hamathecium are 1.0-1.8 $\mu \mathrm{m}$ wide, cellular pseudoparaphyses, anastomosing above asci, embedded in a gelatinous matrix. Asci are 70-108 $\times 7.5-11.0 \mu \mathrm{m}(\bar{x}=85.1 \times 9.3 \mu \mathrm{m}, n=20)$, 8-spored, bitunicate, cylindrical to clavate, with short furcate pedicel, apically rounded, with an ocular chamber. Ascospores are 16.0-23.5 $\times 3.0-5.5 \mu \mathrm{m}(\bar{x}=20.1 \times 4.5 \mu \mathrm{m}, n=50)$, overlapping biseriate, hyaline to pale brown, fusoid, 1-3-septate, constricted at the center septum, guttulate when young, smooth, surrounded by a gelatinous sheath. Asexual morph: Undetermined.

Culture characteristics: Colonies on PDA and attaining a diameter about $13 \mathrm{~mm}$ after 21 days at $25^{\circ} \mathrm{C}$, circular, medium dense, dark olive green, reverse dark green.

Material examined: CHINA, Guizhou Province, Guiyang City, Kaiyang County, Nanjiang Gorge Scenic Area, 26 57'24" N, 10659'19" E, $2900 \mathrm{ft}$ Elevation, on decaying petioles of Trachycarpus fortunei (Arecaceae), 19 March 2019, S.N. Zhang, SNC53 (HKAS 113021, holotype); ex-type living culture CGMCC 3.20404; ibid., 2657'36" N, 106 59'34" E, $2860 \mathrm{ft}$ Elevation, on decaying petioles of Trachycarpus fortunei (Arecaceae), 19 March 2019, S.N. Zhang, SNC50 (GZAAS 21-0045, paratype); living culture GZCC 21-0184. 
Notes: Neooccultibambusa kaiyangensis are clustered with the generic type N. chiangraiensis with absolute bootstrap support (100\% ML/100\% MP/1.00 BYPP, Figure 1). However, they can be recognized as different species. $N$. kaiyangensis differs from $N$. chiangraiensis [3] in having relatively smaller asci $(70-108 \times 7.5-11.0$ vs. $(70-) 115-160(-207) \times 14-21)$ and ascospores (16.0-23.5 × 3.0-5.5 vs. (33-)36-37(-43) $\times$ 8-13) (Table 2). The comparison of molecular data of $N$. kaiyangensis and $N$. chiangraiensis showed that there are $0.65 \%(3 / 457)$ nucleotide differences in ITS and 1.6\% (10/613) in TEF1 $\alpha$ gene regions. Although these differences are minimal, $N$. kaiyangensis has formed a separate branch in the multi-gene phylogeny. The morphological and phylogenetic differences support the delineation of $N$. kaiyangensis as a new species.
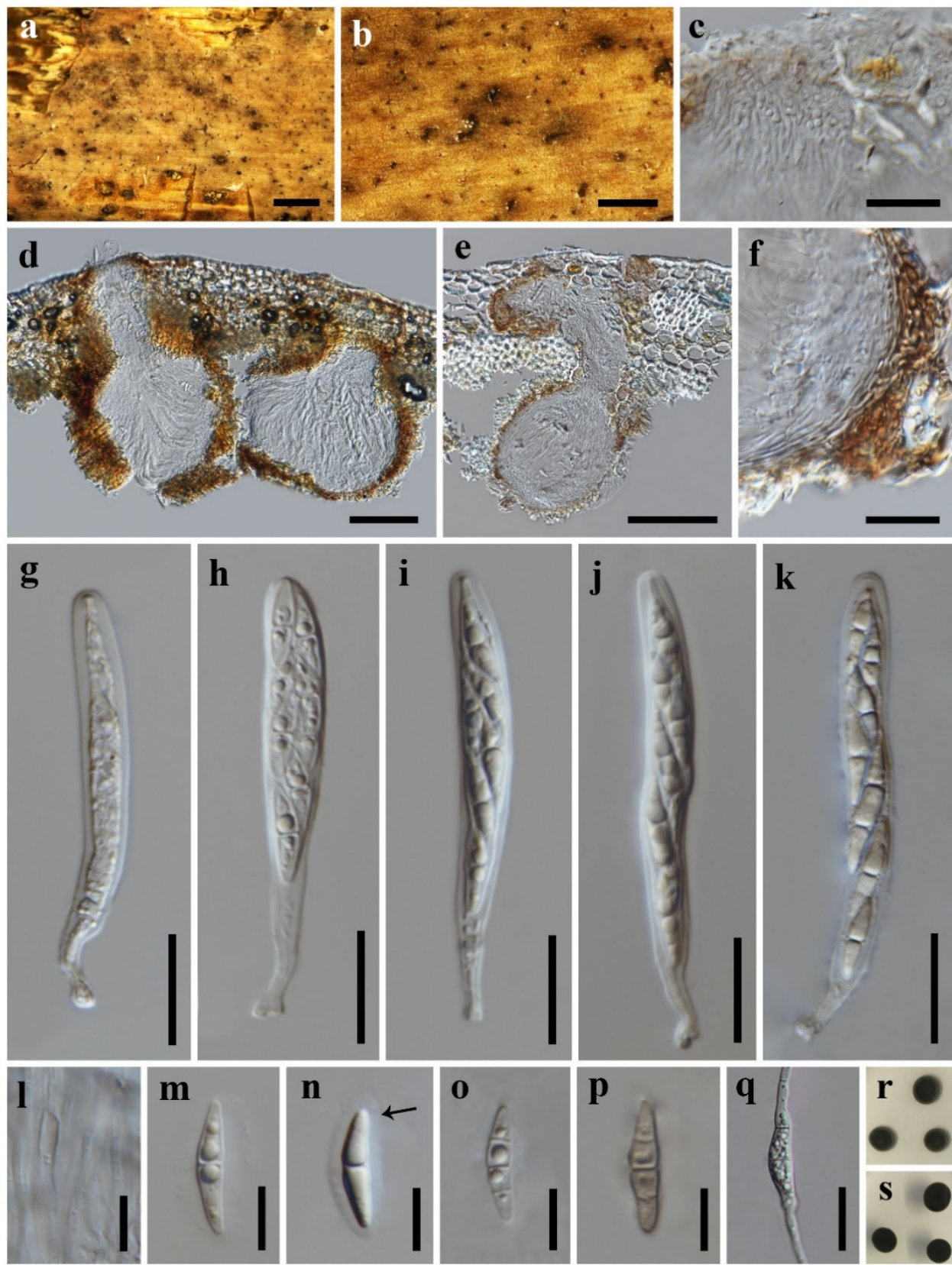

Figure 3. Neooccultibambusa kaiyangensis (HKAS 113021, holotype) (a,b) Ascomata on host substrate. (c) Ostiole with periphyses (d,e) Vertical section of ascoma. (f) Structure of peridium. (g-k) Asci. (1) Pseudoparaphyses. (m-p) Ascospores (n) Arrow indicated mucilaginous sheath). (q) Germinated ascospore. $(\mathbf{r}, \mathbf{s})$ Colonies on PDA, above (r), reverse (s). Scale bars: $(\mathbf{a})=1000 \mu \mathrm{m}$, $(\mathbf{b})=500 \mu \mathrm{m},(\mathbf{c}, \mathbf{f}-\mathbf{k}, \mathbf{q})=20 \mu \mathrm{m},(\mathbf{d}, \mathbf{e})=100 \mu \mathrm{m},(\mathbf{l}-\mathbf{p})=10 \mu \mathrm{m}$. 
Table 2. Comparative morphological data on species of Neooccultibambusa.

\begin{tabular}{|c|c|c|c|c|c|c|}
\hline \multirow{2}{*}{ Taxa } & \multicolumn{2}{|c|}{ Ascomata } & \multirow{2}{*}{ Asci ( $\mu \mathrm{m})$} & \multicolumn{2}{|c|}{ Ascospores } & \multirow{2}{*}{$\begin{array}{l}\text { Refer- } \\
\text { ences }\end{array}$} \\
\hline & Morphology & Size $(\mu \mathrm{m})$ & & Morphology & Size $(\mu \mathrm{m})$ & \\
\hline N. chiangraiensis ${ }^{1}$ & $\begin{array}{l}\text { Immersed to } \\
\text { erumpent, without a } \\
\text { neck, globose to } \\
\text { subglobose }\end{array}$ & $\begin{array}{c}(250-) 345-355(- \\
400) \times \\
(230-) 245-295(- \\
325)\end{array}$ & $\begin{array}{c}(70-) 115-160(- \\
207) \times \\
14-21\end{array}$ & $\begin{array}{c}\text { Fusoid, hyaline to pale } \\
\text { brown, } 1-3 \text { septate, with } \\
\text { a sheath }\end{array}$ & $\begin{array}{c}(33-) 36-37(-43) \times \\
8-13\end{array}$ & {$[3]$} \\
\hline N. jonesii ${ }^{2}$ & $\begin{array}{l}\text { Immersed to } \\
\text { erumpent, without a } \\
\text { neck, globose to } \\
\text { subglobose }\end{array}$ & $\begin{array}{c}104-155 \times \\
130-160\end{array}$ & $47-76 \times 8-10$ & $\begin{array}{l}\text { Fusiform, brown when } \\
\text { matrure, 1-septate, } \\
\text { submedian, without a } \\
\text { sheath }\end{array}$ & $15-20 \times 2.5-4.5$ & {$[8]$} \\
\hline N. kaiyangensis & $\begin{array}{l}\text { Immersed to } \\
\text { erumpent, without a } \\
\text { neck, depressed } \\
\text { globose or irregular }\end{array}$ & $\begin{array}{c}200-360 \times \\
110-270\end{array}$ & $70-108 \times 7.5-11.0$ & $\begin{array}{l}\text { Fusiform, hyaline to } \\
\text { pale brown, 1-3-septate, } \\
\text { with a sheath }\end{array}$ & $\begin{array}{c}16.0-23.5 \times \\
3.0-5.5\end{array}$ & $\begin{array}{l}\text { This } \\
\text { study }\end{array}$ \\
\hline N. thailandensis & $\begin{array}{l}\text { Superficial, globose } \\
\text { to subglobose }\end{array}$ & $65-80 \times 44-61$ & $34-51 \times 5-8$ & $\begin{array}{c}\text { Fusiform, } \\
\text { yellow-brown, } \\
\text { 1-septate, without a } \\
\text { sheath }\end{array}$ & $6-11 \times 2-3.5$ & {$[10]$} \\
\hline \multirow[t]{3}{*}{ N. trachycarpi } & $\begin{array}{l}\text { Immersed to } \\
\text { erumpent, without a } \\
\text { neck, depressed } \\
\text { globose or irregular }\end{array}$ & $\begin{array}{c}150-240 \times \\
140-200\end{array}$ & $48-120 \times 10-15$ & $\begin{array}{l}\text { Fusiform, hyaline, } \\
\text { 1-septate, becoming } \\
\text { light brown and present } \\
\text { two pseudosepta when } \\
\text { senescent, with a sheath }\end{array}$ & $12-19 \times 3.0-5.0$ & $\begin{array}{l}\text { This } \\
\text { study }\end{array}$ \\
\hline & \multicolumn{2}{|c|}{ Conidiophores } & \multirow{2}{*}{$\begin{array}{l}\text { Conidiogenous } \\
\text { cells size }(\mu \mathrm{m})\end{array}$} & \multicolumn{2}{|c|}{ Conidia (Chlamydospores) } & \\
\hline & morphology & size $(\mu \mathrm{m})$ & & morphology & size $(\mu \mathrm{m})$ & \\
\hline N. pandanicola ${ }^{3}$ & $\begin{array}{l}\text { Pale-brown to } \\
\text { brown, 3-5-septate }\end{array}$ & $13-71 \times 3.5-7$ & $2.5-5.5 \times 4-5.5$ & $\begin{array}{l}\text { Obclavate, olivaceous } \\
\text { brown to mid-brown, } \\
\text { 7-17-euseptate }\end{array}$ & $28-150 \times 7-21$ & [9] \\
\hline
\end{tabular}

${ }^{1}$ N. chiangraiensis: the asexual morph was known as chlamydospores in culture, which is characterized by hyaline to brown, 1-septate, subglobose chlamydospores, $(7.5-) 12-14(-16) \times(8.5-) 12-14(-17)$ [3]. ${ }^{2}$ N. jonesii: the asexual morph was observed in culture, which is characterized by dark brown, septate conidiophores, with pale to dark brown, unicellular, subglobose to globose conidia, chlamydosporelike, 10-14(-16) × 8-14(-17) [8]. ${ }^{3}$ N. pandanicola: it is an asexual morph species found on dead leaves of Pandanus.

Neooccultibambusa trachycarpi X.D. Yu, S.N. Zhang \& Jian K. Liu, sp. nov., Figure 4. MycoBank: MB 841011;

Etymology: The epithet "trachycarpi" in reference to the host plant genus "Trachycarpus". Holotype: HKAS 113020.

Saprobic on decaying petioles of Trachycarpus fortunei. Sexual morph: Ascomata are solitary to gregarious, scattered, immersed to erumpent, visible as small, black dots on host surface, in vertical section 150-240 $\mu \mathrm{m}$ high, 140-200 $\mu \mathrm{m}$ diam., uniloculate, depressed globose or irregular, ostiolate. Ostiole are circular, central, periphysate. Peridium are 11-38 $\mu \mathrm{m}$ wide, composed of pale brown to brown textura angularis cells, thicker outwardly. Hamathecium are 2.0-3.2 $\mu \mathrm{m}$ wide, hyphae-like, cellular pseudoparaphyses, embedded in a gelatinous matrix. Asci 48-120 × 10-15 $\mu \mathrm{m}(\bar{x}=75.3 \times 12.1 \mu \mathrm{m}, n=20)$, 8 -spored, bitunicate, cylindric-clavate, with a short furcate to rounded pedicel, apically rounded, with an ocular chamber. Ascospores are 12-19 $\times 3.0-5.0 \mu \mathrm{m}(\bar{x}=15.6 \times 3.9 \mu \mathrm{m}$, $n=50$ ), overlapping biseriate, hyaline, fusiform, tapering towards the ends, 1-septate, constricted at the center septum, becoming pale brown and present two pseudosepta when senescent (Figure 4r), guttulate when young, smooth, surrounded by mucilaginous sheath Asexual morph: Undetermined.

Culture characteristics: Colonies growing well on PDA and attaining a diameter about $12 \mathrm{~mm}$ after 21 days at $25^{\circ} \mathrm{C}$, circular, medium dense, olive green, reverse dark green.

Material examined: CHINA, Guizhou Province, Guiyang City, Kaiyang County, Nanjiang Gorge Scenic Area, 26 56'28" N, 106 58'12" E, $2800 \mathrm{ft}$ Elevation, on decaying petioles of Trachycarpus fortunei (Arecaceae), 19 March 2019, S.N. Zhang, SNC40 (HKAS 113020, holo- 
type), ex-type living culture CGMCC 3.20405; ibid., SNC39, (GZAAS 21-0043, paratype), living culture GZCC 21-0181.
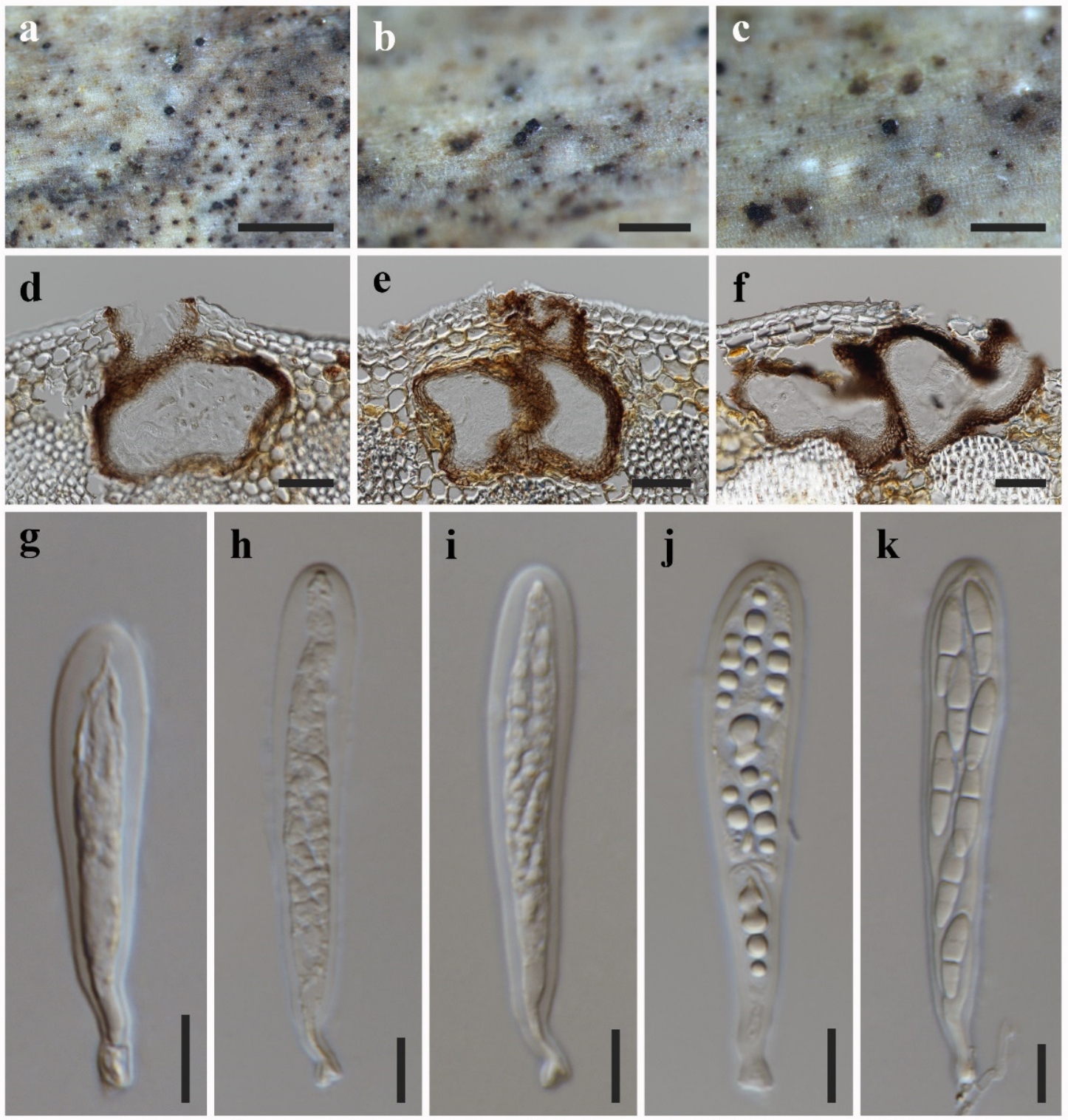

k
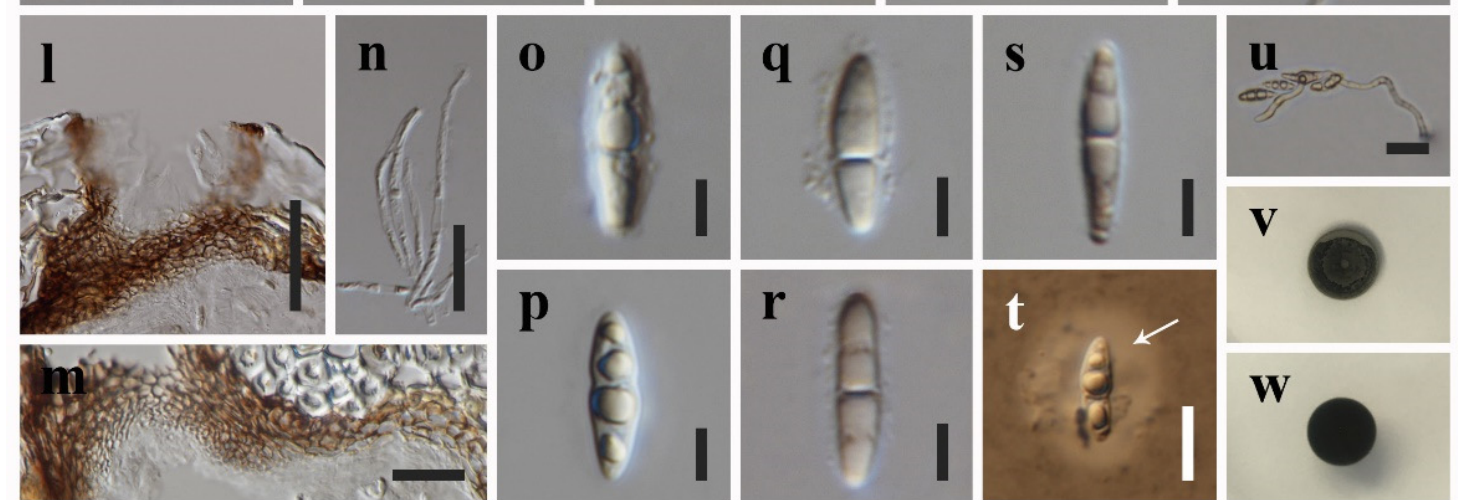

Figure 4. Neooccultibambusa trachycarpi (HKAS 113020, holotype) (a-c) Ascomata on host substrate. (d-f) Vertical section of ascoma. (g-k) Asci. (1) Ostiole, showing periphyses. (m) Structure of peridium. (n) Pseudoparaphyses. (o-t) Ascospores $((\mathbf{t})$ Arrow indicated mucilaginous sheath). (u) Germinated ascospores. $(\mathbf{v}, \mathbf{w})$ Colonies on PDA, above $(\mathbf{v})$, reverse (w). Scale bars: $(\mathbf{a}, \mathbf{b})=1000 \mu \mathrm{m},(\mathbf{c})=500 \mu \mathrm{m},(\mathbf{d}-\mathbf{f}, \mathbf{l})=50 \mu \mathrm{m},(\mathbf{g}-\mathbf{k}, \mathbf{t})=10 \mu \mathrm{m},(\mathbf{m}, \mathbf{n}, \mathbf{u})=20 \mu \mathrm{m},(\mathbf{o}-\mathbf{s})=5 \mu \mathrm{m}$. 
Notes: Neooccultibambusa trachycarpi resembles N. chiangraiensis and N. kaiyangensis in having immersed ascomata, fusiform, hyaline to pale brown, septate ascospores with mucilaginous sheath. However, $N$. trachycarpi differs from the latter ones in having hyaline, 1-septate ascospores, which become pale brown when senescent and present two pseudosepta. The ascospores dimensions are also different (Table 2). The phylogenetic results (Figure 1) showed that Neooccultibambusa trachycarpi clustered with $N$. chiangraiensis and N. kaiyangensis and formed a distinct lineage within Neooccultibambusa. The establishment of the new species Neooccultibambusa trachycarpi is justified by morphological and phylogenetic evidence.

\section{Discussions}

A recent contribution to Occultibambusaceae is the introduction of new species for Occultibambusa and Serisacoma [30]. It also discussed that Occultibambusa and Versicolorisporium are phylogenetically related, but they are different genera due to their significant difference in asexual morphs [30]. In this study, multi-gene phylogenetic analyses showed our samples were affiliated to Brunneofusispora and Neooccultibambusa, respectively.

Based on a blastn search of LSU sequence data of Brunneofusispora inclinatiostiola in NCBI GenBank, the closest hits are Massarina rubi (MUT 4323, identities 98.11\%, query cover 100\%; MUT 4887, identities 97.76\%, query cover 100\%), Brunneofusispora sinensis (MFLUCC 20-0016, identities $97.96 \%$, query cover 98\%). A blastn search of LSU sequence data of Neooccultibambusa trachycarpi in NCBI GenBank, the closest hits are Massarina sp. (MUT 4863, identities $98.31 \%$, query cover $100 \%$; MUT 4860, identities $97.47 \%$, query cover $100 \%$ ), Brunneofusispora hyaline (MFLU 21-0016, identities $97.35 \%$, query cover 100\%), followed by Massarina rubi (MUT 4887, identities 97.35\%), Neooccultibambusa thailandensis (MFLUCC 16-0274, identities 96.68\%), N. pandanicola (KUMCC 17-0179, identities 96.68\%). Therefore, phylogenetic analysis was performed based on different matrices with the inclusion of those Massarina sp. and/or Massarina rubi (data not shown) and the multi-gene phylogeny result (Figure 1) supports the recognition of three new species. On the other hand, the genus Neooccultibambusa is not monophyletic (Figure 1), of which N. thailandensis formed an independent lineage in Occultibambusaceae. However, this is consistent with recent relevant studies [6,30] and further studies are needed to provide a better understanding towards the classification of Neooccultibambusa with more sampling and taxa population included in the analysis.

Karst landscape is attractive to tourists but also inhabits rich biodiversity due to its typical low temperature and high humidity environment. The fan palm Trachycarpus fortunei (Arecaceae) is native to subtropical and temperate mountain forests of China and 23 fungal species have been described from this plant [31,32]. The three new species introduced herein were found on Trachycarpus fortunei in a karst region. Additionally, Occultibambusa jonesii and $O$. maolanensis were also reported from karst landforms in China [12]. It is noteworthy that they are distributed in three different genera in Occultibambusaceae. Although this is only a small sample of data, it reflects somehow the hidden fungal diversity of palms and the karst formations.

Author Contributions: Conceptualization, J.-K.L., X.-D.Y. and S.-N.Z.; methodology, S.-N.Z.; formal analysis, X.-D.Y.; resources, S.-N.Z.; data curation, X.-D.Y.; writing-original draft preparation, X.-D.Y. and S.-N.Z.; writing-review and editing, X.-D.Y., S.-N.Z. and J.-K.L.; supervision, J.-K.L. and R.C.; project administration, J.-K.L.; funding acquisition, J.-K.L. All authors have read and agreed to the published version of the manuscript.

Funding: This study was supported by the Joint Fund of the National Natural Science Foundation of China and the Karst Science Research Center of Guizhou province (Grant No. U1812401).

Institutional Review Board Statement: Not applicable.

Informed Consent Statement: Not applicable. 
Data Availability Statement: The data is available upon request form the corresponding authors. The data is not publicly available due to its usage in the ongoing study.

Acknowledgments: X.-D.Y. thanks Yan-Peng Chen for his valuable suggestions and help on phylogenetic analysis.

Conflicts of Interest: The authors declare no conflict of interest.

\section{References}

1. Dai, D.Q.; Phookamsak, R.; Wijayawardene, N.N.; Li, W.J.; Bhat, D.J.; Xu, J.C.; Taylor, J.E.; Hyde, K.D.; Chukeatirote, E. Bambusicolous fungi. Fungal Divers. 2017, 82, 1-105. [CrossRef]

2. Hatakeyama, S.; Tanaka, K.; Harada, Y. Bambusicolous fungi in Japan (7): A new coelomycetous genus, Versicolorisporium. Mycoscience 2008, 49, 211-214. [CrossRef]

3. Doilom, M.; Dissanayake, A.J.; Wanasinghe, D.N.; Boonmee, S.; Liu, J.K.; Bhat, D.J.; Taylor, J.E.; Bahkali, A.H.; Mckenzie, E.H.C.; Hyde, K.D. Microfungi on Tectona grandis (teak) in Northern Thailand. Fungal Divers. 2017, 82, 107-182. [CrossRef]

4. Phookamsak, R.; Hyde, K.D.; Jeewon, R.; Bhat, D.J.; Jones, E.B.G.; Maharachchikumbura, S.S.N.; Raspé, O.; Karunarathna, S.C.; Wanasinghe, D.N.; Hongsanan, S.; et al. Fungal diversity notes 929-1035: Taxonomic and phylogenetic contributions on genera and species of fungi. Fungal Divers. 2019, 95, 1-273. [CrossRef]

5. $\quad$ Dong, W.; Wang, B.; Hyde, K.D.; McKenzie, E.H.C.; Raja, H.A.; Tanaka, K.; Abdel-Wahab, M.A.; Abdel-Aziz, F.A.; Doilom, M.; Phookamsak, R.; et al. Freshwater Dothideomycetes. Fungal Divers. 2020, 105, 319-575. [CrossRef]

6. Wanasinghe, D.N.; Wijayawardene, N.N.; Xu, J.C.; Cheewangkoon, R.; Mortimer, P.E. Taxonomic novelties in Magnolia-associated pleosporalean fungi in the Kunming Botanical Gardens (Yunnan, China). PLoS ONE 2020, 15, e0235855. [CrossRef]

7. Rathnayaka, A.; Dayarathne, M.; Maharachchikumbura, S.S.N.; Liu, J.K.J.; Hyde, K.D. Introducing Seriascoma yunnanense sp. nov. (Occultibambusaceae, Pleosporales) based on evidence from morphology and phylogeny. Asian J. Mycol. 2019, 2, 245-253. [CrossRef]

8. Jayasiri, S.C.; Hyde, K.D.; Jeewon, R.; Bhat, J.D.; Camporesi, E.; Kang, J.C. Neooccultibambusa jonesii, a novel taxon within Occultibambusaceae. Mycosphere 2016, 7, 1458-1472. [CrossRef]

9. Hyde, K.D.; Chaiwan, N.; Norphanphoun, C.; Boonmee, S.; Camporesi, E.; Chethana, K.W.T.; Dayarathne, M.C.; de Silva, N.I.; Dissanayake, A.J.; Ekanayaka, A.H.; et al. Mycosphere notes 169-224. Mycosphere 2018, 9, 271-430. [CrossRef]

10. Tibpromma, S.; Hyde, K.D.; McKenzie, E.H.C.; Bhat, D.J.; Phillips, A.J.L.; Wanasinghe, D.N.; Samarakoon, M.C.; Jayawardena, R.S.; Dissanayake, A.J.; Tennakoon, D.S.; et al. Fungal diversity notes 840-928: Micro-fungi 4 associated with Pandanaceae. Fungal Divers. 2018, 93, 1-160. [CrossRef]

11. Hyde, K.D.; Hongsanan, S.; Jeewon, R.; Bhat, D.J.; McKenzie, E.H.C.; Jones, E.B.G.; Phookamsak, R.; Ariyawansa, H.A.; Boonmee, S.; Zhao, Q.; et al. Fungal diversity notes 367-490: Taxonomic and phylogenetic contributions to fungal taxa. Fungal Divers. 2016, 80, 1-270. [CrossRef]

12. Zhang, J.F.; Liu, J.K.; Hyde, K.D.; Yang, W.; Liu, Z.Y. Fungi from Asian Karst formations II. Two new species of Occultibambusa (Occultibambusaceae, Dothideomycetes) from karst landforms of China. Mycosphere 2017, 8, 550-559. [CrossRef]

13. Phukhamsakda, C.; McKenzie, E.H.C.; Phillips, A.J.L.; Gareth Jones, E.B.; Jayarama Bhat, D.; Marc, S.; Bhunjun, C.S.; Wanasinghe, D.N.; Thongbai, B.; Camporesi, E.; et al. Microfungi associated with Clematis (Ranunculaceae) with an integrated approach to delimiting species boundaries. Fungal Divers. 2020, 102, 1-203. [CrossRef]

14. Calabon, M.S.; Jones, E.B.G.; Boonmee, S.; Doilom, M.; Lumyong, S.; Hyde, K.D. Five Novel Freshwater Ascomycetes Indicate High Undiscovered Diversity in Lotic Habitats in Thailand. J. Fungi 2021, 7, 117. [CrossRef]

15. Senanayake, I.; Rathnayake, A.; Marasinghe, D.; Calabon, M.; Gentekaki, E.; Lee, H. Morphological approaches in studying fungi: Collection, examination, isolation, sporulation and preservation. Mycosphere 2020, 11, 2678-2754. [CrossRef]

16. Chomnunti, P.; Hongsanan, S.; Aguirre-Hudson, B.; Tian, Q.; Peršoh, D.; Dhami, M.K.; Alias, A.S.; Xu, J.C.; Liu, X.Z.; Stadler, M. The sooty moulds. Fungal Divers. 2014, 66, 1-36. [CrossRef]

17. Crous, P.W.; Gams, W.; Stalpers, J.A.; Robert, V.; Stegehuis, G. MycoBank: An online initiative to launch mycology into the 21st century. Stud. Mycol. 2004, 50, 19-22.

18. Vilgalys, R.; Hester, M. Rapid genetic identification and mapping of enzymatically amplified ribosomal DNA from several Cryptococcus species. J. Bacteriol. 1990, 172, 4238-4246. [CrossRef]

19. White, T.J.; Bruns, T.; Lee, S.; Taylor, J. Amplification and direct sequencing of fungal ribosomal RNA genes for phylogenetics. PCR Protoc. A Guide Methods Appl. 1990, 18, 315-322. [CrossRef]

20. Liu, Y.J.; Whelen, S.; Hall, B.D. Phylogenetic relationships among ascomycetes: Evidence from an RNA polymerse II subunit. Mol. Biol. Evol. 1999, 16, 1799-1808. [CrossRef] [PubMed]

21. Rehner, S.A.; Buckley, E. A Beauveria phylogeny inferred from nuclear ITS and EF1- $\alpha$ sequences: Evidence for cryptic diversification and links to Cordyceps teleomorphs. Mycologia 2005, 97, 84-98. [CrossRef] [PubMed]

22. Kazutaka, K.; Standley, D.M. MAFFT multiple sequence alignment software version 7: Improvements in performance and usability. Mol. Biol. Evol. 2013, 30, 772-780. [CrossRef]

23. Hall, T.A. BioEdit: A user-friendly biological sequence alignment editor and analysis program for Windows 95/98/NT. Nucleic Acids Symp. Ser. 1999, 41, 95-98. 
24. Dissanayake, A.J.; Bhunjun, C.S.; Maharachchikumbura, S.S.M.; Liu, J.K. Applied aspects of methods to infer phylogenetic relationships amongst fungi. Mycosphere 2020, 11, 2652-2676. [CrossRef]

25. Silvestro, D.; Michalak, I. raxmlGUI: A graphical front-end for RAxML. Org. Divers. Evol. 2011, 12, 335-337. [CrossRef]

26. Swofford, D.L. PAUP*: Phylogenetic Analysis Using Parsimony ( ${ }^{*}$ and Other Methods); Sinauer Associates: Sunderland, UK, 2003.

27. Nylander, J.A.A. MrModeltest V2. Program distributed by the author. In Evolutionary Biology Centre; Uppsala University: Uppsala, Sweden, 2004.

28. Rannala, B.; Yang, Z. Probability distribution of molecular evolutionary trees: A new method of phylogenetic inference. J. Mol. Evol. 1996, 43, 304-311. [CrossRef]

29. Huelsenbeck, J.P.; Ronquist, F. MRBAYES: Bayesian inference of phylogenetic trees. Bioinformatics 2001, 17, 754-755. [CrossRef]

30. Jiang, H.B.; Phookamsak, R.; Hyde, K.D.; Mortimer, P.E.; Xu, J.C.; Kakumyan, P.; Karunarathna, S.C.; Kumla, J. A taxonomic appraisal of bambusicolous fungi in Occultibambusaceae (Pleosporales, Dothideomycetes) with new collections from Yunnan Province, China. Life 2021, 11, 932. [CrossRef] [PubMed]

31. Taylor, J.E.; Hyde, K.D. Microfungi of Tropical and Temperate Palms; Fungal Diversity Press, The University of Hong Kong: Hong Kong, 2003; pp. 1-459.

32. Liu, J.K. Phylogeny of Ascomycetes from Palms; Mae Fah Luang University: Chiang Rai, Thailand, 2014. 